\section{AEG \\ RESEARCH \\ and}

DEVELOPMENT

REPORT

\title{
NEUTRONICS CHARACTERISTICS of SELECTED COMPACT FAST REACTORS
}

JULY. 1966

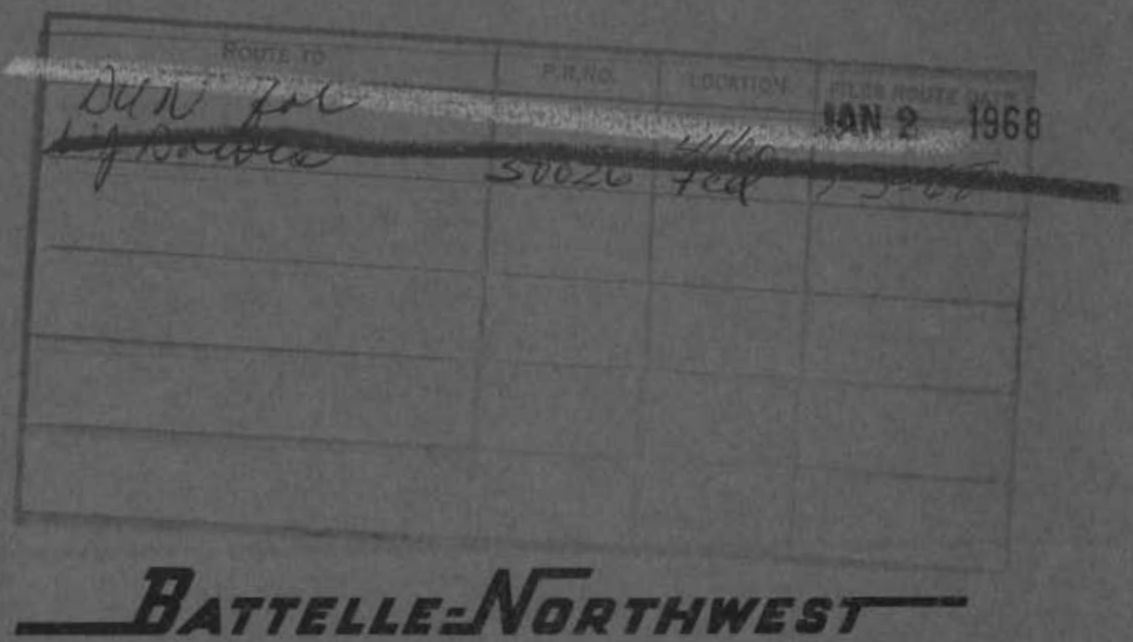

BATTELLE MEMORIAL INSTITUTE/PACIFIC NORTHWEST LABORATORY 


\section{LEGAL NOTICE}

This report was prepared as an account of Government sponsored work. Neither the Unifed States; nor the Commission, nor any person acting on behalf of the Commission:

A. Makes any warranty or representation, expressed or implied, with respect to the accuracy, completeness, or usefulness of the information contained in this report, or that the use of any information, apparatus, method, or process disclosed in this report may not infringe privately owned rights; or

B. Assumes any liabilities with respect to the use of, or for damages resulting from the use of any information, apparatus, method, or process disclosed in this report.

As used in the above, "person acting on behalf of the Commission" includes any employee or contractor of the Commission, or employee of such contractor, to the extent that such employee or contractor of the Commission, or employee of such contractor prepares, disseminates, or provides access to, any information pursuant to his employment or contract with the Commission, or his employment with such contractor.

\section{PACIFIC NORTHWEST LABORATORY}

RICHLAND, WASHINGTON

operated by

BATTELLE MEMORIAL INSTITUTE

for the

UNITED STATES ATOMIC ENERGY COMMISSION UNDER CONTRACT AT(45-1)-1830 
BNWL -283

UC-80, Reactor Technology

\section{NEUTRONICS CHARACTERISTICS \\ of \\ SELECTED COMPACT FAST REACTORS}

by

W.W. Little, Jr。 and R。W. Hardie

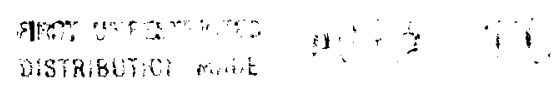

$$
\text { July, } 1966
$$

PACIFIC NORTHWEST LABORATORY

RICHLAND, WASHINGTON 
Printed in USA. Price \$2.00. Avilable from the Clearinghouse for Federal Scientific and Technical Information National Bureau of Standards

U.S. Department of Commerce Springfield, Virgina 


\section{ABSTRACT}

This report describes the neutronics characteristics of $\mathrm{U}^{235} \mathrm{O}_{2}-\mathrm{W}, \mathrm{U}^{233} \mathrm{O}_{2}-\mathrm{W}$, and $\mathrm{Pu}^{239} \mathrm{~N}-\mathrm{W}$ fueled fast compact reactors. The principal items studied are reactor criticality and fuel burnup.

For the fuel compositions and void fractions considered, $\mathrm{U}^{233}$ and $\mathrm{Pu}^{239}$ fueled reactors require considerably less fuel than corresponding $U^{235}$ fueled reactors. Al1 reactors considered are rather insensitive to changes in the refractory metal inventory. 


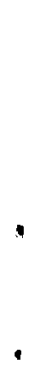




\section{TABLE OF CONTENTS}

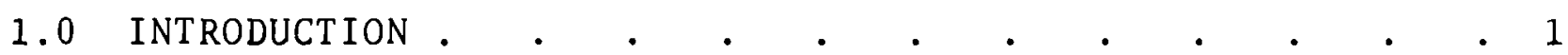

2.0 CRITICAL SIZE SURVEY . . . . . . . . . . . . 2

3.0 REACTIVITY COEFFICIENT CALCULATIONS . . . . . . . 10

4.0 BURNUP RELATIONSHIPS . $. \quad . \quad . \quad . \quad . \quad . \quad . \quad . \quad . \quad 15$

5.0 KINETICS CHARACTERISTICS . $. \quad . \quad . \quad . \quad . \quad . \quad . \quad .17$

6.0 OBSERVATIONS ON RESULTS . . . . . . . . . . . . . 19 
, 


\section{NEUTRONICS CHARACTERISTICS \\ of}

\section{SELECTED COMPACT FAST REACTORS}

\subsection{INTRODUCTION}

Compact fast reactors - by virtue of their small volume, high fuel density, and compatibility with refractory materials - offer much promise as lightweight power sources for space applications. $(1-3)$ Further, since $\mathrm{Pu}^{239}$ and $\mathrm{U}^{233}$ fueled fast reactors require less fuel than comparable $U^{235}$ fueled reactors, these high worth fuels may be more suitable than $\mathrm{U}^{235}$ for use in compact space reactors.

This report portrays the principal neutronics characteristics of $\mathrm{U}^{235} \mathrm{O}_{2}-\mathrm{W}, \mathrm{U}^{233} \mathrm{O}_{2}-\mathrm{W}$, and $\mathrm{Pu}{ }^{239} \mathrm{~N}-\mathrm{W}$ fueled fast reactors. A wide range of core sizes and compositions is considered. Emphasis is placed on neutronic-static characteristics, although selected kinetics parameters are also included. The results of the neutronics calculations are given in a form suitable for incorporation into preliminary engineering design studies. 


\subsection{CRITICAL SIZE SURVEY}

This section describes the dependence of reactor size on void fraction and cermet composition [fuel to fuelplus-metal ratio, designated $F /(F+M)]$. For each of the three fissile fuels, calculations are performed with void fractions of $0.2,0.35$, and 0.5 and with fuel to cermet ratios $(F /(F+M)$ of $0.3,0.5$, and 0.7 . A more detailed description of the reactor compositions is given in Appendix A。

Two size surveys are shown. The first survey is made with the FCC ${ }^{(4)}$ fundamental mode code and a modified version of the Russian 26-group cross sections. (5) The objective is to describe the basic neutronics-statics characteristics of bare $\mathrm{U}^{235} \mathrm{O}_{2}-\mathrm{W}, \mathrm{U}^{233} \mathrm{O}_{2}-\mathrm{W}$, and $\mathrm{PuN}-\mathrm{W}$ fueled cores. If reflector savings are known, the fundamental mode calculations can be used to represent any simple geometry. The second criticality survey is performed with the DTF-1V $(6)$ one-dimensional transport code $\left(\mathrm{S}_{4}\right.$ option) with eight energy groups. Ail 1-D calculations are performed in spherical geometry with a $10 \mathrm{~cm} \mathrm{BeO} \mathrm{reflector.} \mathrm{For} \mathrm{each} \mathrm{fuel,} \mathrm{8-group}$ cross sections are generated from the 26 -group Russian data.

Figures 2.1 through 2.3 give the fundamental mode spherical radius $\left(R=\pi / \sqrt{B^{2}}\right.$ ) as a function of void fraction and for fuel to cermet ratio for $U^{235} \mathrm{O}_{2}-\mathrm{W}, \mathrm{U}^{233} \mathrm{O}_{2}-\mathrm{W}$, and $\mathrm{PuN}-\mathrm{W}$ fueled cores, respectively. Figure 2.4 - a cross-plot from Figures 2.1 through 2.3 - shows the spherical radius of each fuel ror a fuel to cermet ratio of 0.5 .

The one-dimensional calculations of core volume as a function of void fraction are shown in Figures 2.5 through 2.7. A cross-plot of these graphs, for a cermet fraction of 0,5 , is shown in Figure 2.8 . 

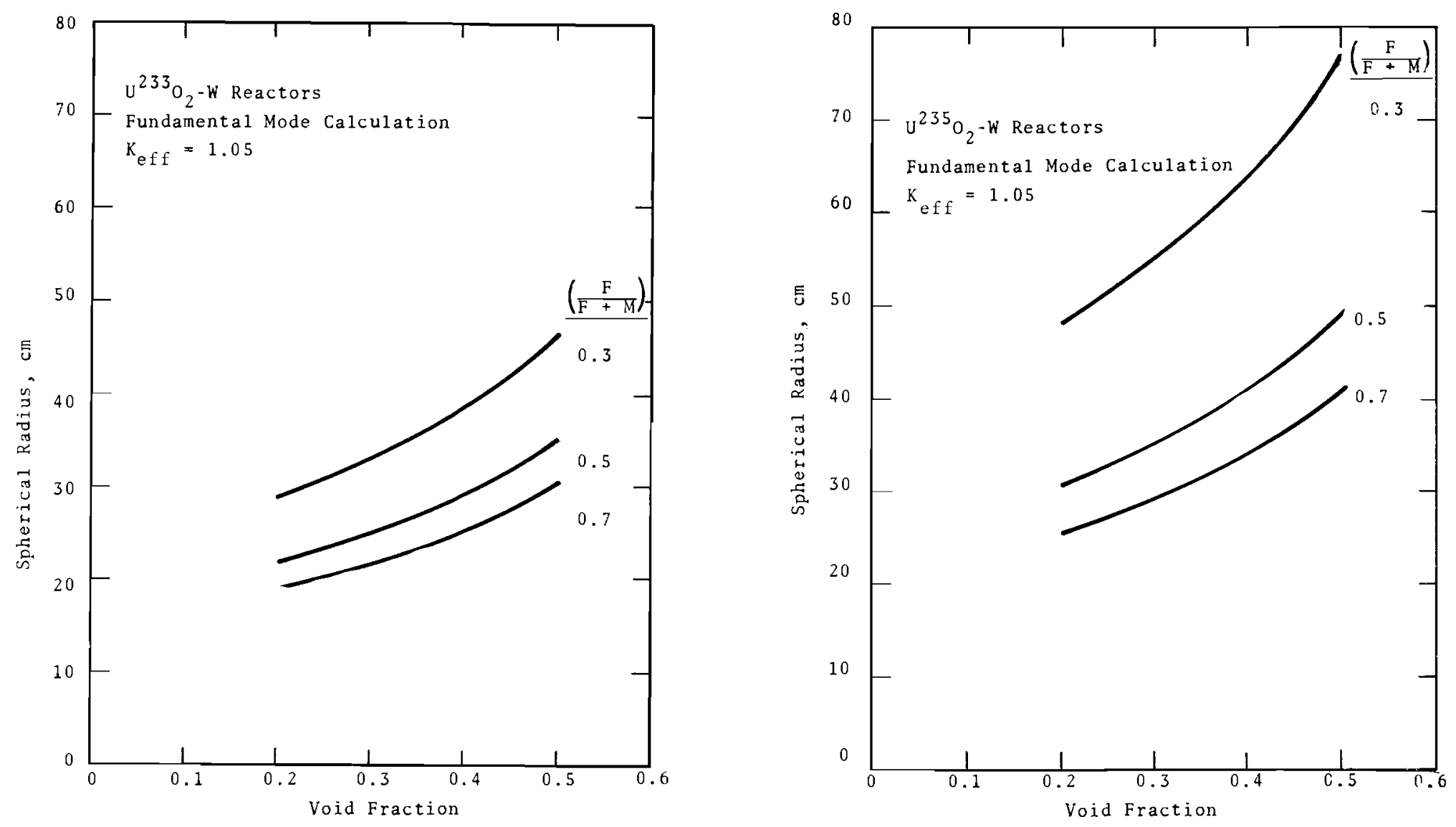

FIGURE 2.1. Spherical Radius Versus Void Fraction for $U^{235} \mathrm{O}_{2}-\mathrm{W}$ Fuezed Cores

FIGURE 2.2. Spherical Radius Versus Void Fraction for $U^{233} \mathrm{O}_{2}-\mathrm{W}$ Fueled Cores 


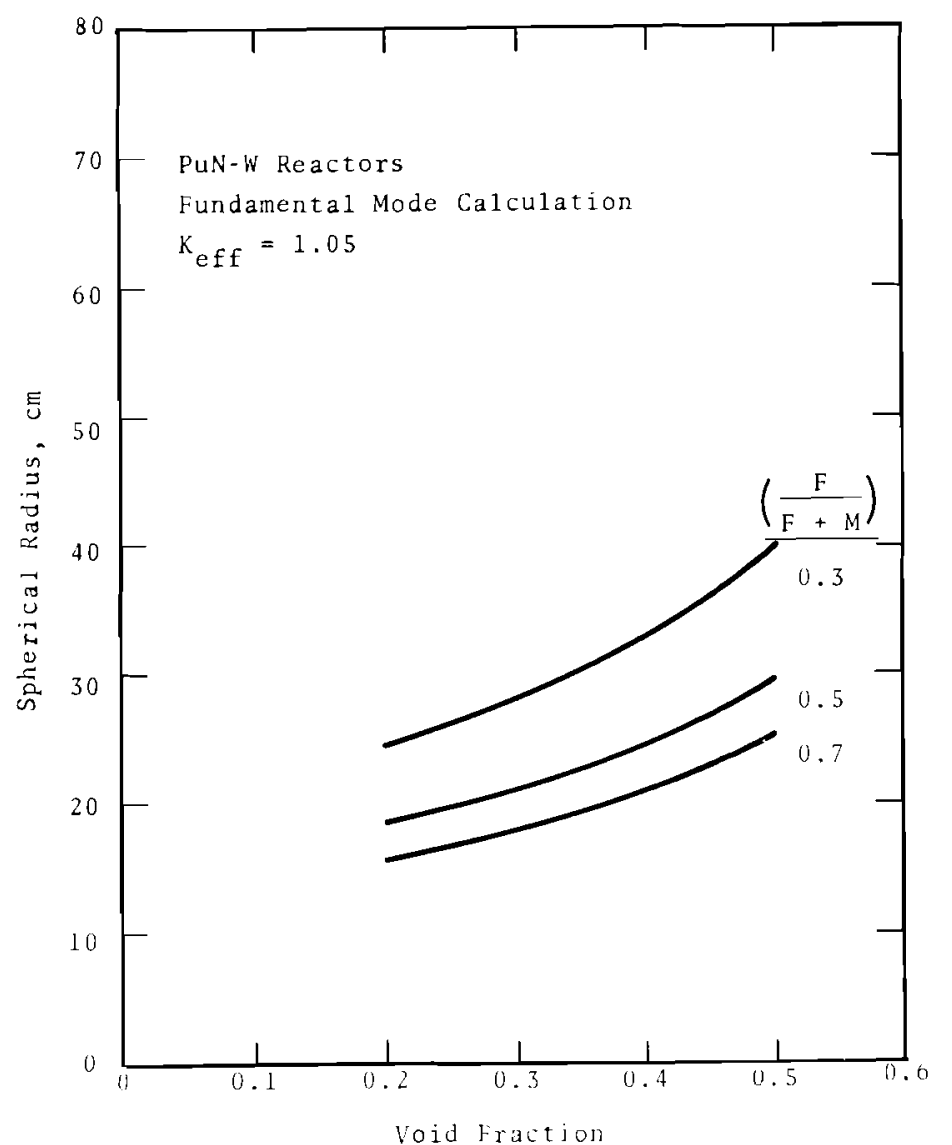

FIGURE 2.3. Spherical Radius Versus Void Fraction for PuN-W Fueled Cores

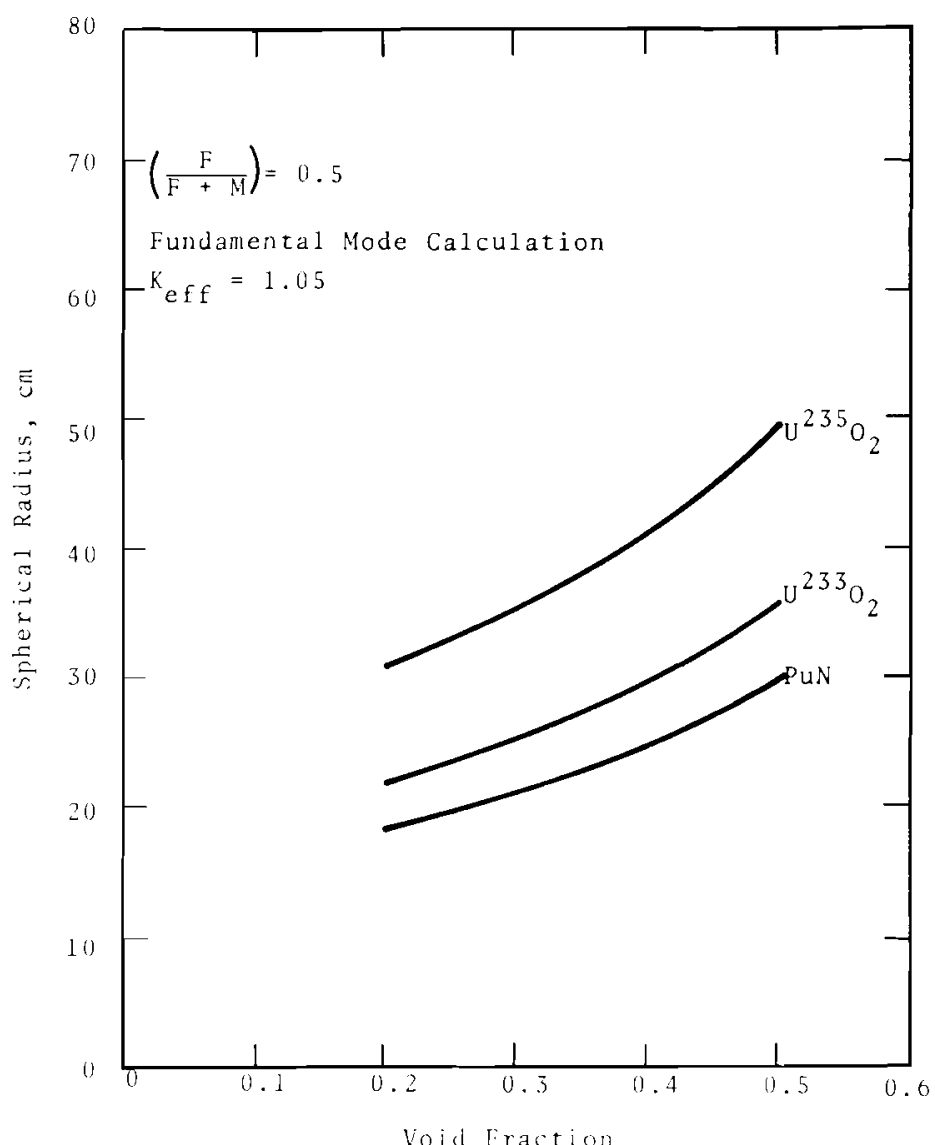

FIGURE 2.4. Spherical Radius Versus Void Fraction for a Fuel-Cermet Ratio of 0.5 $\rightarrow$ 


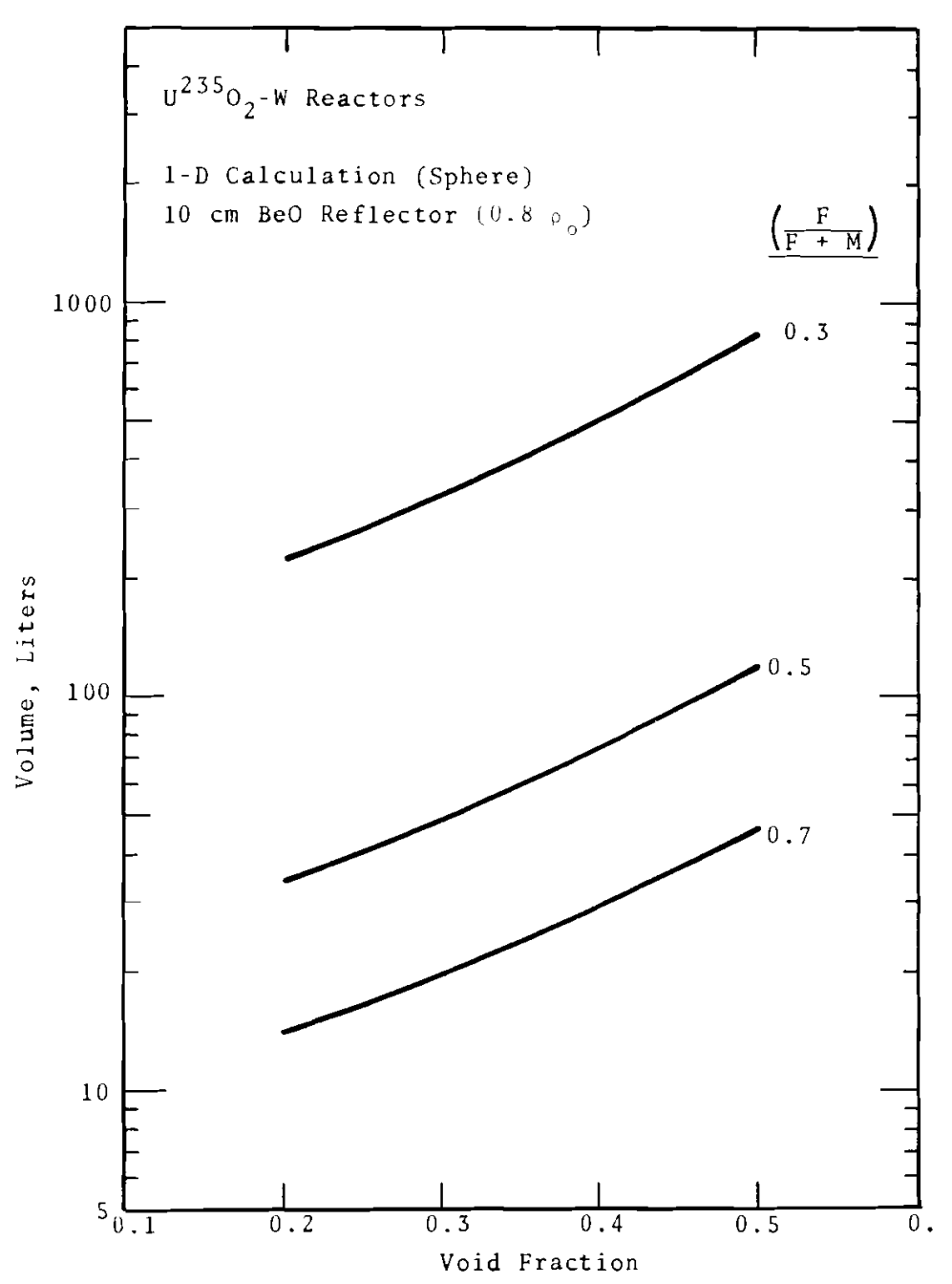

FIGURE 2.5. Core Volume Versus Void Fraction for $U^{235} \mathrm{O}_{2}-\mathrm{W}$ Fueled Reactors

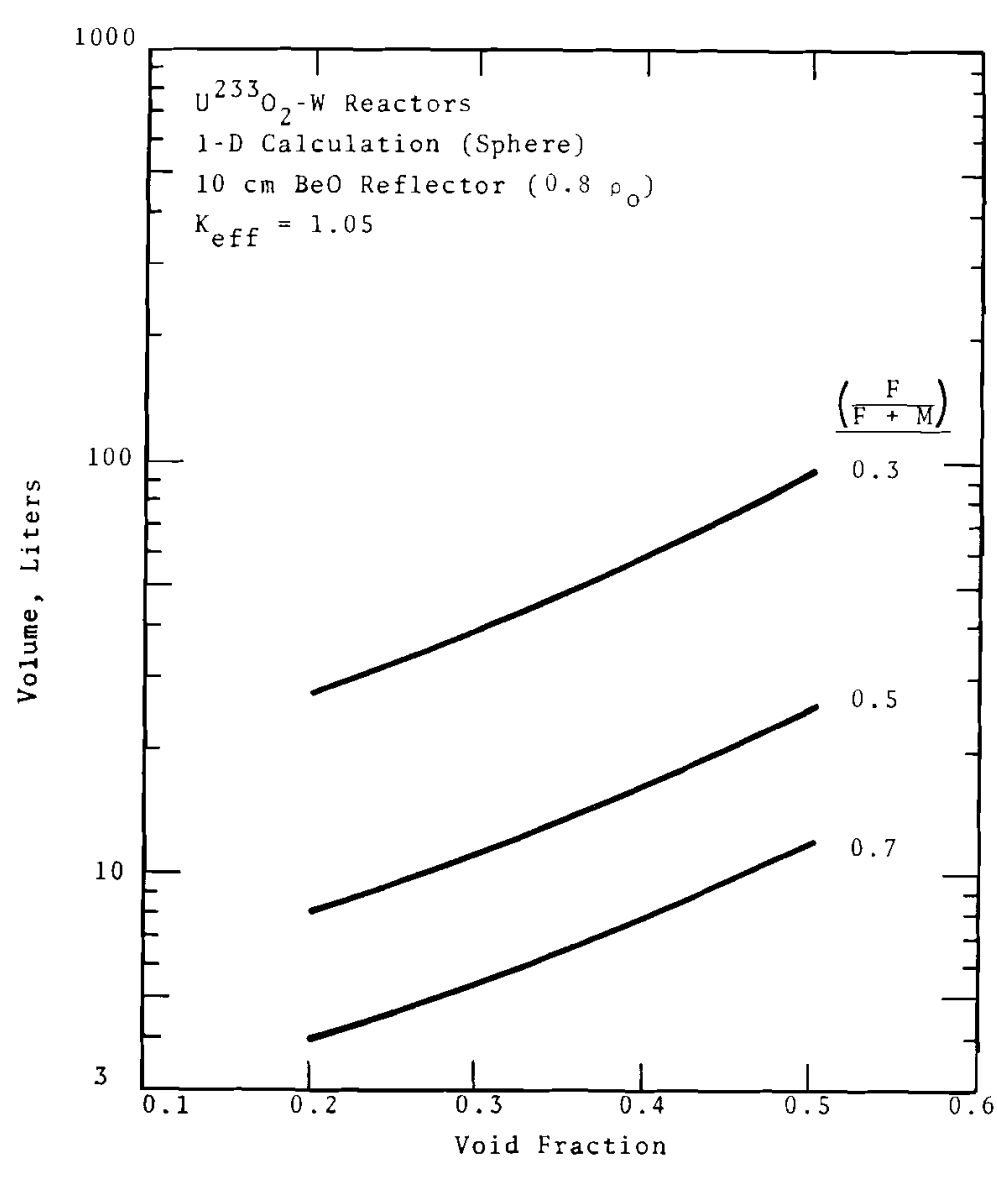

u

FIGURE 2.6. Core Volume Versus Void Fraction for $U^{233} O_{2}-W$ Fueled Reactors 


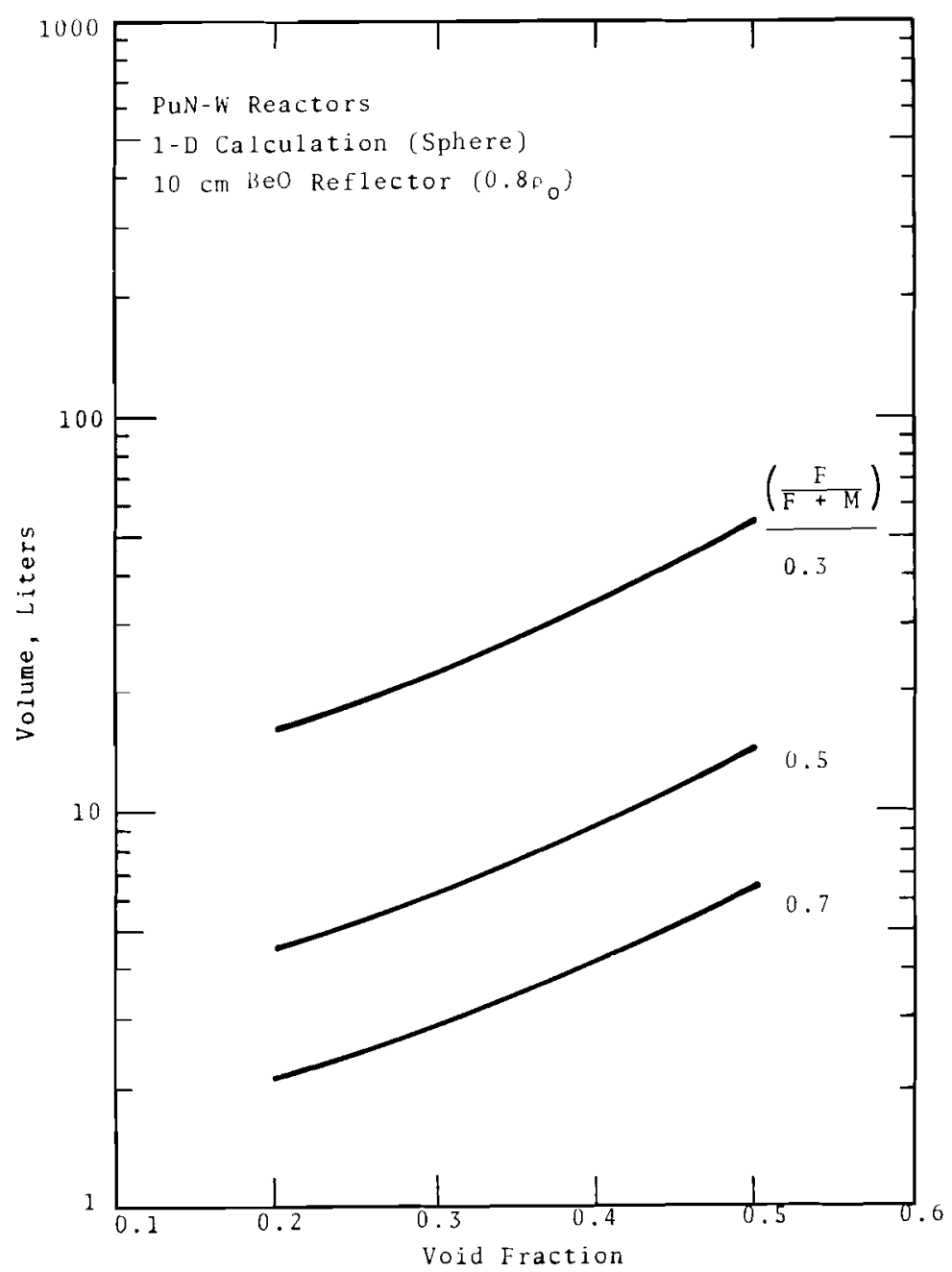

FIGURE 2.7. Core Volume Versus Void Fraction for PuN-W Fueled Reactors

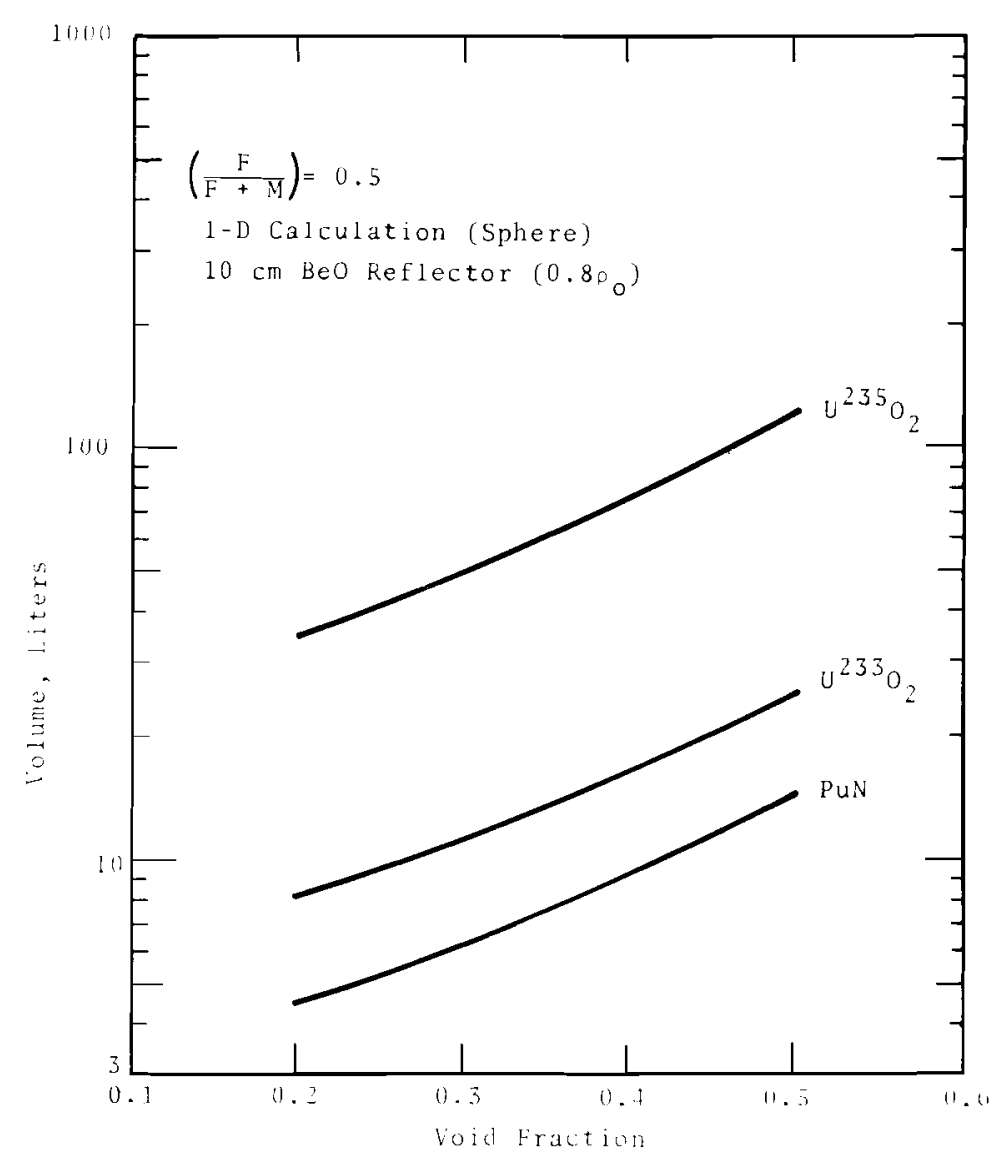

a

FIGURE 2.8. Core Volume Versus Void Fraction for a Fuel-Cermet Ratio of 0.5 
Another comparison of the relative mertis of $\mathrm{U}^{235}, \mathrm{U}^{233}$, and $\mathrm{Pu}^{239}$ can be obtained by comparing the critical masses for comparable reactor configurations. This information is shown in Figures 2.9 through 2.11. In these graphs, $\mathrm{Pu} 239$ and $U^{233}$ fueled cores can be seen to require significantly less fuel than $U^{235}$ fueled cores. This behavior, of course, can be traced to the high $n, v \sigma_{f} / \sigma_{a}$, of $\mathrm{Pu}^{239}$ and $\mathrm{U}^{233}$. 

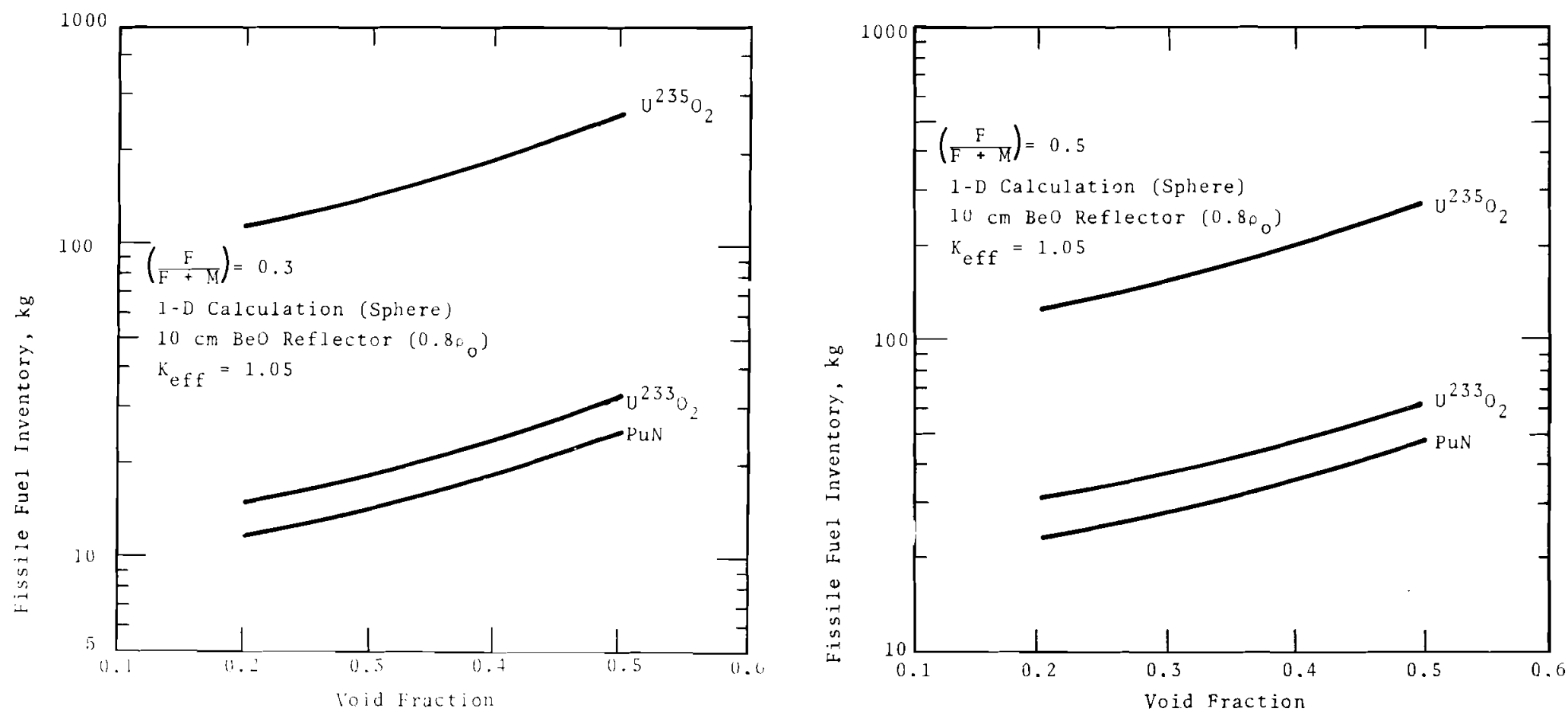

$\infty$

FIGURE 2.9. Critical Mass Versus Void Fraction for a Fuel-Cermet Ratio of 0.3

FIGURE 2.10. Critical Mass Versus Void Fraction for a Fuel-Cermet Ratio of 0.5 


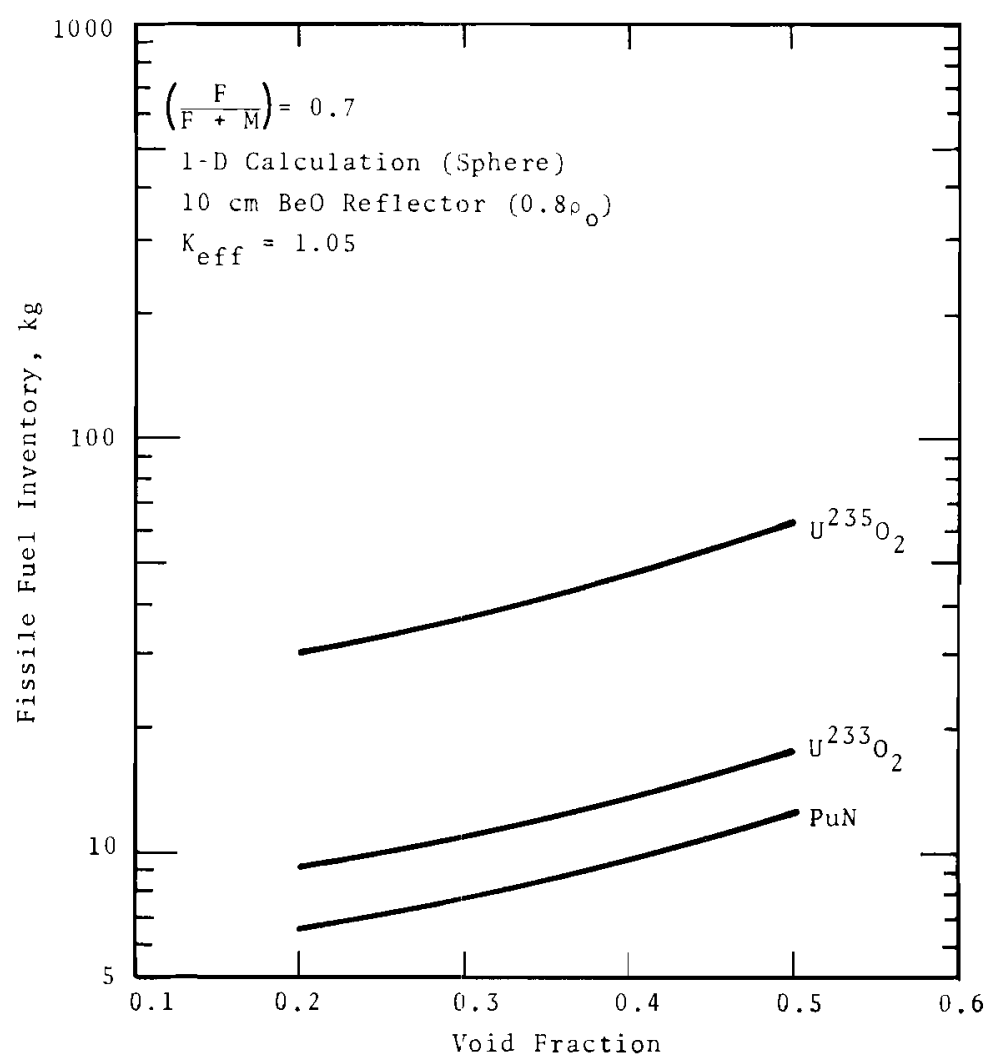

FIGURE 2.11. Critical Mass Versus Void Fraction for a Fuel-Cermet Ratio of 0.7 


\subsection{REACTIVITY COEFFICIENT CALCULATIONS}

In the compact fast reactors under study, materials other than fuels usually have small reactivity worths. These small reactivity coefficients are due, in part, to the extremely hard flux and, thus, low spectrum averaged cross sections. In this section, the reactivity worth of several elements in $\mathrm{U}^{235}, \mathrm{U}^{333}$, and $\mathrm{Pu}^{239}$ fueled cores is described. Both zero and one-dimensional models are employed.

In a bare reactor with energy-independent extrapolation lengths, material worths can be estimated using the perturbation relationship

$\delta K \approx \sum_{i=1}^{N}\left\{\phi_{i} \delta\left(\nu \Sigma^{f}\right)_{i}-\phi_{i} \phi_{i}^{+} \delta\left(\Sigma^{a}\right)_{i}-\phi_{i} \phi_{i}^{+} \delta\left(\frac{B^{2}}{3 \Sigma^{t r}}\right)_{i}-\phi_{i} \sum_{j=i+1}^{N}\left(\phi_{i}^{+}-\phi_{j}^{+}\right) \delta \Sigma(i \rightarrow j)\right\}$

where: $\delta K=$ reactivity change

$$
\begin{aligned}
\phi_{i} & =\text { flux in group } i \\
\phi_{i}^{+} & =\text {adjoint flux in group } i \\
B^{2} & =\text { buckling }\left(\mathrm{cm}^{-2}\right) \\
\delta \Sigma_{i}^{X} & =\text { variation of macroscopic cross section in group } i\left(\mathrm{~cm}^{-1}\right) \\
N & - \text { number of energy groups. }
\end{aligned}
$$

The flux and adjoint flux in Equation (3.1) are normalized by the expressions:

$$
\sum_{i=1}^{N}\left(v \Sigma^{f}\right)_{i} \phi_{i}=
$$

and $\quad \sum_{i=1}^{N} x_{i} \phi_{i}^{+}=1$ 
Observe that the addition of inert material tends to increase reactivity by decreasing leakage and to decrease reactivity via parasitic capture. Depending on the adjoint flux spectrum, the reactivity change due to neutron moderation can be either positive or negative.

Table 3.1 gives the worth of various materials in "typical" $\mathrm{U}^{235}, \mathrm{U}^{233}$, and $\mathrm{Pu}^{239}$ fueled cores. These typical cores-or reference cores-are described in Table 3.2. All calculations were performed using a fundamental mode model with 26 -energy groups. ${ }^{(4,5)}$ The associated flux, adjoint flux, and spectrum averaged cross sections are shown in Figures 3.1 and 3.2 and Table 3.3 .

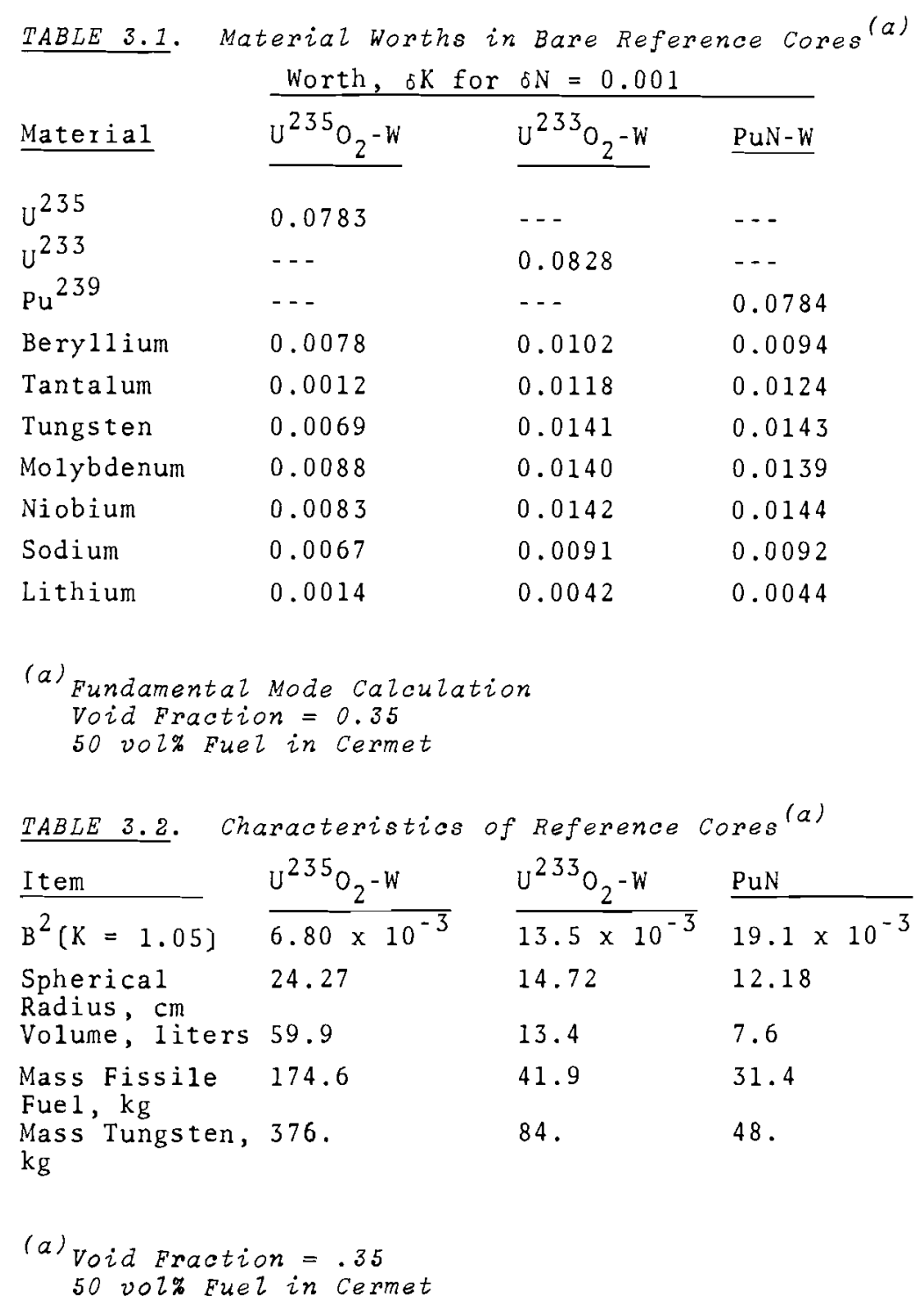




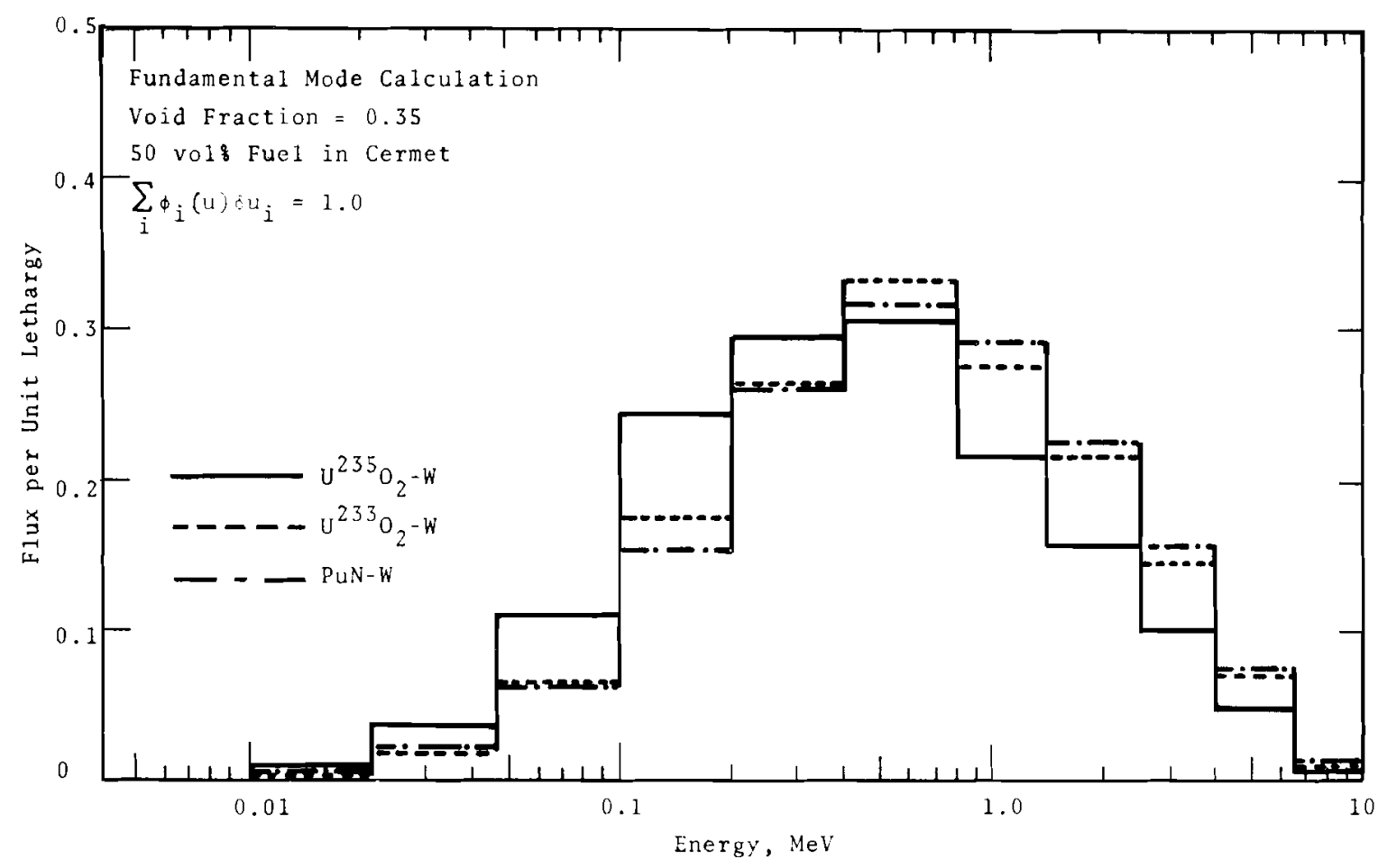

$\frac{\text { FIGURE } 3.1}{\text { Fueled Reactors }}$ Fux spectra in $U^{235}, U^{233}$, and Pu 239

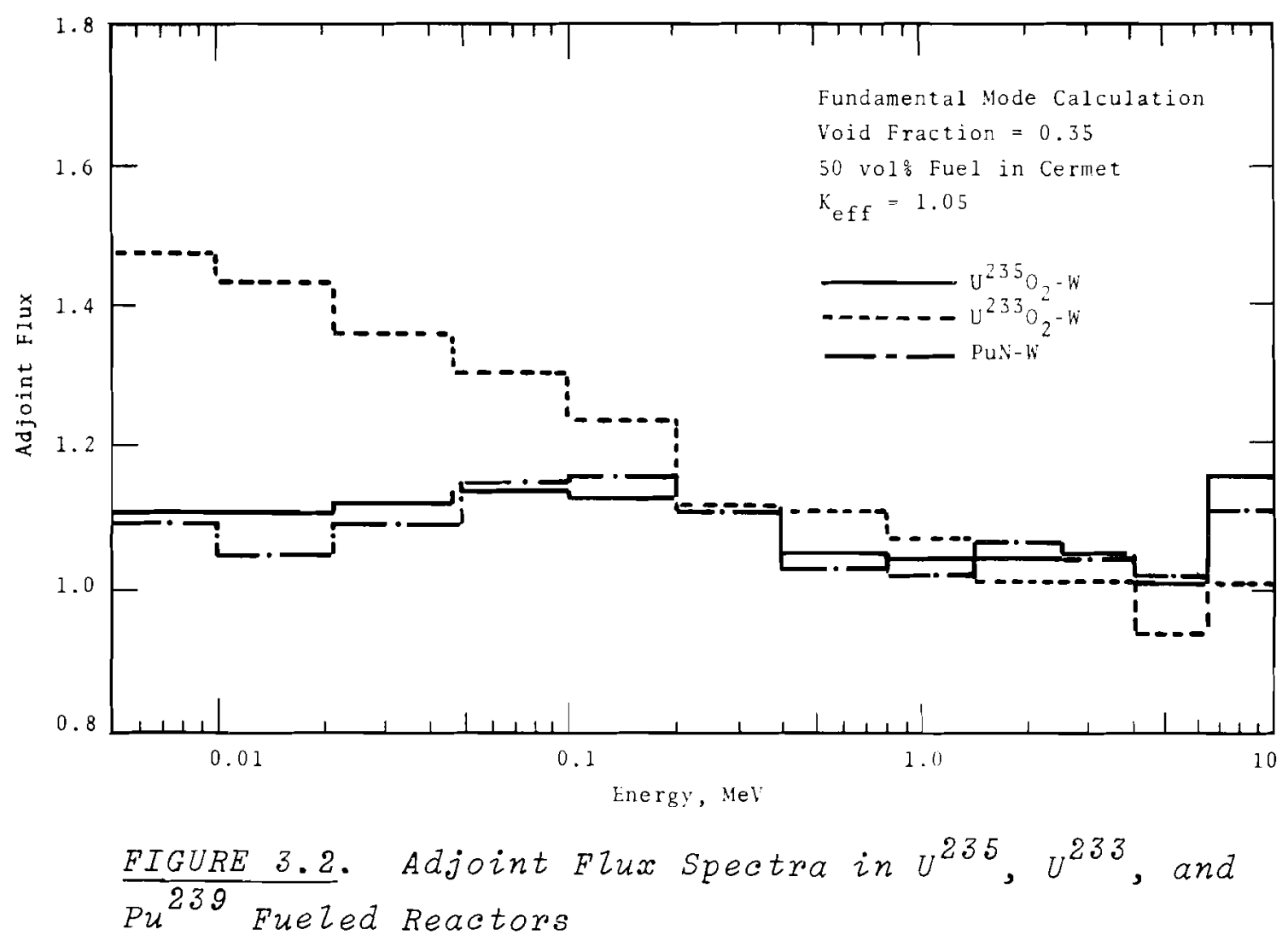


TABLE 3.3. Spectrum Averaged Cross Sections in Reference Reactors $(a)$

Element $\mathrm{U}^{235} \mathrm{O}_{2}-\mathrm{W}$

$\sigma_{a} \mathrm{FF}(\mathrm{b})$

1.6498

$\mathrm{U}^{233} \mathrm{O}_{2}-\mathrm{W}$

PuN

$\sigma_{f F} F$

1. 4060

2.2820

1.8776

vof $F F$

3.5277

2. 1418

1.7541

$\sigma \mathrm{Nb}$

0.0769

5. 5101

5.3081

$\sigma^{\text {Mo }}$

0.0526

0.0600

0.0609

$\sigma$
a
$W$

$\sigma \frac{W}{a}$

0.1183

0.0442

0.0443

$\sigma_{\mathrm{a}}^{\mathrm{Ta}}$

0.2557

0.1021

0.1025

0.2127

0.2151

(a) Fundamental Mode Calculation

Void Fraction $=0.35$

50 vol\% Fuel in cermet

(b) Fissile fuel, either $U^{235}, U^{233}$, or $\mathrm{Pu}^{239}$

Reactivity worths in a reflected $\mathrm{U}^{233} \mathrm{O}_{2}-\mathrm{W}$ fueled reactor are given in Table 3.4. These 1-D (spherical) calculations were performed using the DTF-1V $(6)$ transport code ( $S_{4}$ option) with eight energy groups. The 8 -group cross sections were obtained from FCC by collapsing 26-group data.

of the structural elements considered, observe that tantalum is the most poisonous, followed by tungsten, niobium, and molybdenum. None of these elements, however, significantly penalizes the critical mass requirements. This is true for both bare and reflected cores. 
TABLE 3.4. Material Worth in Reflected $U^{233} \mathrm{O}_{2}-W$ Reactor (a)

\begin{tabular}{llr} 
Material & $\delta M, k g / 1 i$ ter & \\
\cline { 2 - 3 } U $^{233}$ & $\frac{(\delta N=0.001)}{\delta K}$ & 0.0677 \\
Beryllium & 0.0150 & 0.0033 \\
Tantalum & 0.3004 & -0.0031 \\
Tungsten & 0.3052 & 0.0010 \\
Molybdenum & 0.1593 & 0.0024 \\
Niobium & 0.1543 & 0.0017 \\
Sodium & 0.0380 & 0.0022 \\
Lithium & 0.0115 & 0.0003
\end{tabular}

(a) Spherical Reactor

Void Fraction $=0.35$

50 vol\% Fuel in Cermet

$10 \mathrm{~cm}$ BeO Reflector 


\subsection{BURNUP RELATIONSHIPS}

In hard spectrum fast reactors containing no fertile fuel, such as those considered in this report, it is easy to estimate the reactivity variation during burnup. If the flux and adjoint flux are assumed to be independent of both space and energy, it follows that

$$
\delta \mathrm{K} \approx\left(\frac{n-1}{n}\right) \frac{\delta M}{M}
$$

where:

$$
\begin{aligned}
\eta & =\text { eta for fissile isotope }\left(\nu \sigma_{f} / \sigma_{a}\right) \\
M & =\text { fissile inventory } \\
\delta M & =\text { change in fissile inventory } \\
\delta K & =\text { reactivity variation. }
\end{aligned}
$$

The appropriate nuclear parameters for each fuel are 1 isted in Table 4.1. Thus, for a given fuel, $\delta K$ is proportional to the fuel burnup, or mass change, and inversely proportional to the fuel inventory.

TABLE 4.1. Fuel Burnup Parameters $(a)$

Fue1

$\mathrm{U}^{235}$

$\mathrm{U}^{233}$

$\mathrm{Pu}^{239}$

$\frac{n}{2.14}$
2.41
2.83

(a)

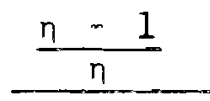

2.53

2.59

0.65
g/MWd

1.23

1.11

1.08

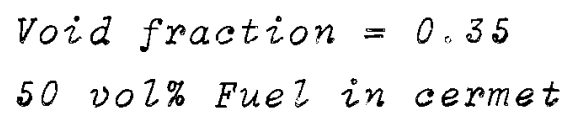

Parenthetically, it should be mentioned that, for a specified energy release, a fast compact reactor has a much smaller reactivity variation than a thermal compact reactor. This difference is due, in part, to the large critical mass requirements in fast reactors. 
Figure 4.1 shows the reactivity as a function of time in $U^{235}$, $\mathrm{U}^{233}$, and $\mathrm{Pu}^{239}$ fueled reactors. These burnup calculations were performed using a fundamental mode model with 26 energy groups. Fission products were included, although they have little effect on reactivity. It can be seen that these numerical results agree reasonably well with preductions given by Equation (4.1).

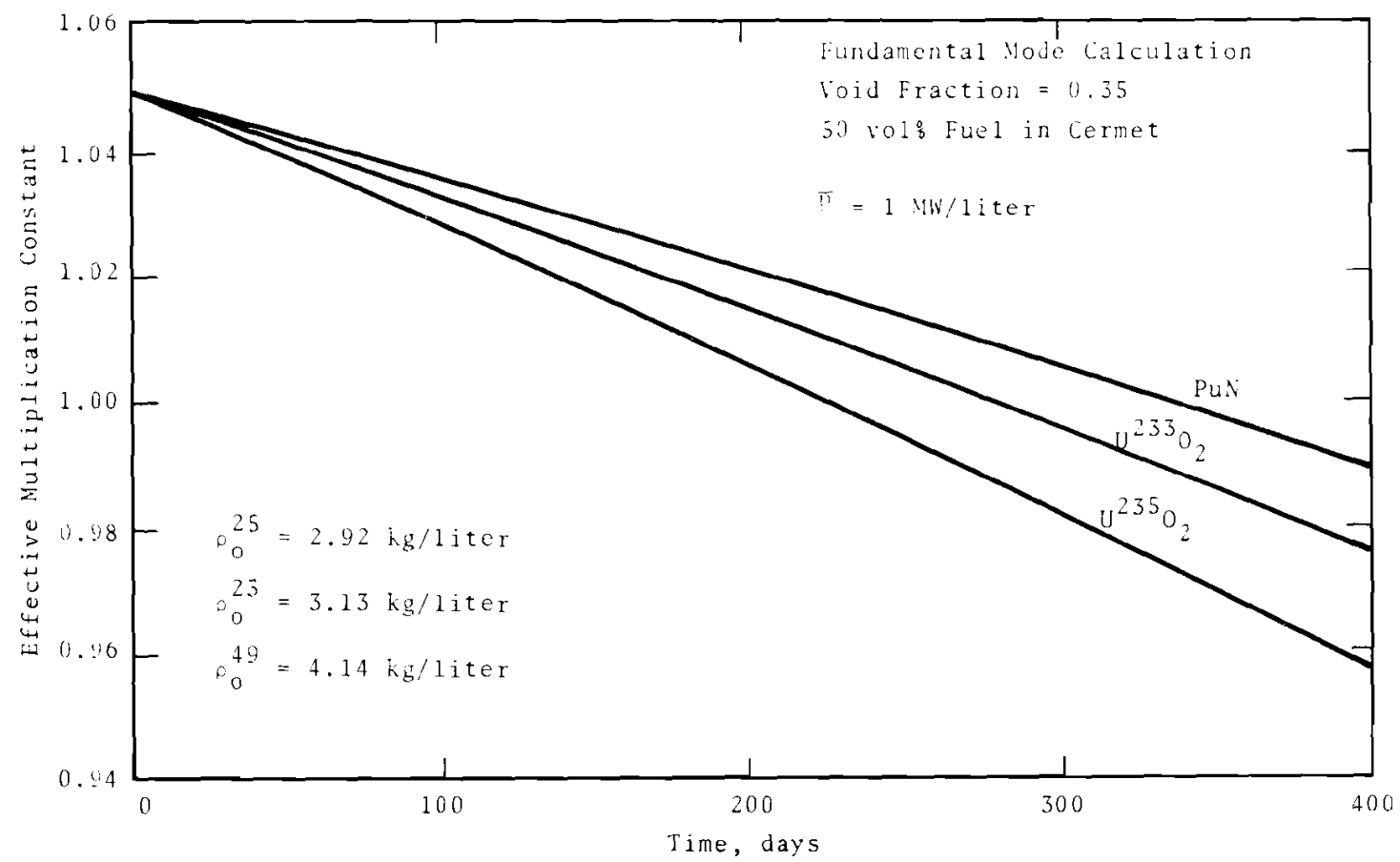

FIGURE 4.1. Effective Multiplication Constant as a Function of Time 


\subsection{KINETICS CHARACTERISTICS}

A detailed kinetics study of compact fast reactors is beyond the scope of this report. However, since the three fissile fuels under study do exhibit markedly different kinetic characteristics, it is of interest to at least identify the principal kinetics parameters.

The most significant kinetics parameter is the delayed neutron fraction, $\beta$. Its influence on reactor kinetics can be understood from the following arguments.

First, let us consider the lumped parameter kinetics equations

$$
\begin{aligned}
& \frac{d P}{d t}=\frac{p-\beta}{\Lambda} P+\sum_{i} \lambda_{i} C_{i} \\
& \frac{d C_{i}}{d t}=\frac{\beta_{i} P}{\Lambda}-\lambda_{i} C_{i},
\end{aligned}
$$

where

$$
\begin{aligned}
P(t) & =\text { power density, } \mathrm{W} / \mathrm{cm}^{3} \\
\rho(t) & =\text { reactivity } \\
C_{i}(t) & =\text { precursor density for group } i, W / \mathrm{cm}^{3} \\
\lambda_{i} & =\text { decay constant for group } i, \mathrm{sec}^{-1} \\
B_{i} & =\text { delay fraction for group } i \\
B & =\text { total delay fraction, } \sum_{i} \beta_{i} \\
\Lambda & =\text { generation time, sec. }
\end{aligned}
$$

If the analysis is restricted to reactivities less than $\beta$, the short-term power variation can be computed using the simple expression

$$
P(t) \approx \frac{P_{0}}{1-\frac{P(t)}{B}}
$$

where $P_{0}$ is the initial power (at equilibrium). 
For the sake of argument, let us now suppose that $\rho \ll \beta$ 。 From Equation $(5.3)$,

$$
P(t) \approx P_{0}\left[1+\frac{p(t)}{\beta}\right] \text {. }
$$

Thus, for a specified reactivity variation, $\rho(t)$, the change in reactor power is inversely proportional to the delayed neutron fraction, $\beta$. Since the delayed neutron fraction (see Table 5.1) for $\mathrm{U}^{233}$ and $\mathrm{Pu}^{239}$ is roughly $1 / 3$ that of $\mathrm{U}^{235}$, reactors fueled with $\mathrm{U}^{233}$ and $\mathrm{Pu}^{239}$ are more sensitive to small reactivity variations. For the same reason, $U^{233}$ and $\mathrm{Pu}^{239}$ fueled reactors are-under most circumstances-more susceptible to prompt critical excursions.

The above arguments per se do not preclude, or in any sense restrict, the use of $\mathrm{U}^{2 \overline{33}}$ or $\mathrm{Pu}^{239}$ fuels in compact fast reactors. The safety of any reactor can only be evaluated by a detailed study of the reactor, its objective, and its envitonment.

\section{TABLE 5.1. Approximate Delayed Neutron Fractions}

Delayed Neutrons Delayed Neutrons

Fue 1

Per Fission (7)

Per Fission Neutron( $\beta$ )

$\mathrm{U}^{235}$

0.0165

$\sim 0.0064$

$\mathrm{U}^{233}$

0.0070

ح0.0026

$\mathrm{Pu}^{239}$

0.0063

.0 .0021 


\subsection{OBSERVATIONS ON RESULTS}

Perhaps the most significant, and most obvious, characteristic discussed in this report is the low critical mass requirements in $\mathrm{U}^{233}$ and $\mathrm{Pu}^{239}$ fueled reactors. If these high worth fuels could be used in place of $U^{235}$, one could:

- Design a smaller reactor for a given void fraction and cermet loading

- Reduce the cermet (fuel to metal ratio) loading for a given core size and void fraction

- Increase the void fraction for a specified core size and cermet loading.

Thus, since power plant size and weight are of critical importance in space applications, it appears that $\mathrm{Pu}^{239}$ and $\mathrm{U}^{233}$ fuels are potentially more suitable for space employment than $\mathrm{U}^{235}$ fuels。 
APPENDIX A

Material Densities

Material

Molybdenum

Niobium

Tungsten

Tantalum

Sodium

Lithium

$\mathrm{BeO}$

$\mathrm{Be}$

0

PuN

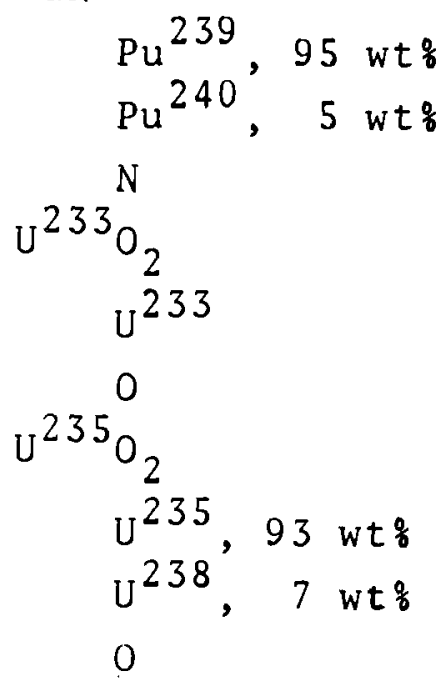

p, $\mathrm{g} / \mathrm{cm}^{3}$

10.2

8.4

19.3

16.6

0.872

0.534

2.86

$-$

$\overline{14} .2$

$-$

$-$

$-$

10.97

$-$

-

10.97

$-$
$\mathrm{N}$, atoms $/ \mathrm{b}-\mathrm{cm}$

0.06403

0.05445

0.06322

0.05525

0.02284

0.04634

-

0.06887

0.06887

-

0.03210

0.00169

0.03379

-

0.02493

0.04986

0.02299

0.00173

0.04945 


\section{REFERENCES}

1. R. S. Cooper. Fast Reactor Rocket Engines-Criticality, LA-2707. Los Alamos Scientific Laboratory, Los Alamos, New Mexico, october, 1962.

2. D. G. Ott. "Space Applications of Fast Reactors," Fast Reactor Technology, ANS-100. pp. 57-64. American Nuclear Society, Hinsdale, Illinois, Apriz, 1965.

3. L. L. Maas and P. L. Hofmann. Nuclear Parameter Survey for Some Compact, Fast Spectrum, Cermet Reactors, HW-78756. General Electric Company, Richland, Washington, 1963.

4. W. W. Little, Jr. and R. W. Hardie. FCC-A Fundamental Mode Code for Fast Reactor Analysis, BNWL-234. March, $\overline{1966 .}$

5. I. I. Bondarenko et al. Group Constants for Nuclear Reactor Calculations. Consultants Bureau, New York, 1964.

6. K. D. Lathrop. DTF-IV, a FORTRAN-IV Program for Solving the Multi-group Transport Equation with Anisotropic Scattering, LA-3373. Los Alamos Scientific Laboratory, Los Alamos, New Mexico, November, 1965.

7. G. R. Keepin. Physics of Nuclear Kinetics. Addison-Wesley Publishing Company, Inc., Palo Alto, California, 1965. 


\section{DISTRIBUTION}

Number of Copies 9

Atomic Energy Commission, Washington

Division of Reactor Development and

Technology

I. F。 Zartman, Chief, Reactor

Physics Branch

M。J. Whitman, Assistant Director, Office of Reactor

Engineering

Division of Space Nuclear Systems

C. E. Johnson, Chief, Reactor Power

Col.G. K. Dicker Systems Branch (5)

R. A. Anderson

Division of Technical Information Extension

Richland Operations Office

R. K. Sharp

Technical Information Library

Battelle-Northwest

F. W. Albaugh

E. R. Astley

W。 L。Bunch

G。J Busselman

J L L Carter

F。 G. Daws on

D。E。Deonigi

E。A。Eschbach

J.F。Fletcher

J. C。 Fox

R. W. Hardie

R。A. Harris

H. Harty

R. E. Heineman

P. L. Hofmann

R. H. Holeman

D. D. Lanning

C. E. Leach

C.W. Lindemeier

W. W. Little, Jr. (20)

L. L. Maas

R. E. Peterson

W. W. Porath

$\mathrm{J}$ 。J Regimba1

R。E。 Schenter

L. C. Schmid

Technical Information Files (5)

Technical Publications (2) 